\title{
Binding of Ligands to GPCRs - How Valid is a Thermodynamic Discrimination of Antagonists and Agonists?
}

\author{
Andrea Strasser ${ }^{1 *}$ and Hans-Joachim Wittmann ${ }^{2}$ \\ ${ }^{1}$ Department of Pharmaceutical/Medicinal Chemistry II, University of Regensburg, Regensburg, Germany \\ ${ }^{2}$ Faculty of Chemistry and Pharmacy, University of Regensburg, Regensburg, Germany
}

\begin{abstract}
In 1979, a thermodynamic discrimination between antagonists and agonists at GPCRs was discussed in literature for the first time. Subsequently a small number of experimental studies, addressing not only Gibbs energy but also enthalpy and entropy of ligand binding were performed within the last 30 years at different GPCRs. Some of these studies support the suggested "thermodynamic discrimination", but this concept does not hold for all GPCRs analyzed by thermodynamic methods so far. This review presents an overview in this field of research. Furthermore, the data presented in literature are critically discussed and related to each other. As experimental methods provide information about the final and the starting state of the ligand-receptor binding, specific sub-processes are not accessible. But in the framework of an interpretation on a molecular level, quantitative insights in these processes are essential. A workaround of this problem is given by the development of molecular modelling methods, during the last decade. Taking into account all data so far, the concept of "thermodynamic discrimination" between antagonists and agonists may be extended to "thermodynamic and kinetic discrimination" of antagonists, partial agonists and full agonists. However, to obtain a deeper insight on molecular level, more systematic studies, including a large number of compounds with high structural variety have to be performed.
\end{abstract}

Keywords: Agonist; Antagonist; Enthalpy; Entropy; Gibbs energy; Gibbs energy of activation; GPCR; Kinetic discrimination; Molecular modelling; Thermodynamic discrimination

Abbreviations: $A_{1} R$ : Adenosine $A_{1}$ Receptor; $A_{2 A} R$ : Adenosine $A_{2 A}$ Receptor; $A_{2 B} R$ : Adenosine $A_{2 B}$ Receptor; $A_{3} R$ : Adenosine $A_{3}$ Receptor; Cpd: Compound; $\mathrm{D}_{2} \mathrm{R}$ : Dopamine $\mathrm{D}_{2}$ Receptor; $\mathrm{E}_{\mathrm{max}}$ : Efficacy; gp: Guinea-pig; GPCR: G-Protein Coupled Receptor; h: Human; $H_{1} R$ : Histamine $\mathrm{H}_{1}$ Receptor; $\mathrm{H}_{3} \mathrm{R}$ : Histamine $\mathrm{H}_{3}$ Receptor; $\mathrm{r}$ : rat; 5- $\mathrm{HT}_{1 \mathrm{~A}} \mathrm{R}$ : Serotonine 5-HT $\mathrm{HT}_{1 \mathrm{~A}}$ Receptor; $\beta \mathrm{R}$ : $\beta$-Adrenergic Receptors; $\beta_{2} \mathrm{R}$ : Adrenergic $\beta_{2}$ Receptor; $\mathrm{CB}_{1}$ : Cannabinoid receptor; $\mathrm{CB}_{2}$ : Cannabinoid receptor; $\mathrm{CCK}_{2}$ : Cholecystokinin receptor

\section{Introduction}

G protein coupled receptors (GPCRs), which play an important role in several physiological and pathophysiological processes, and thus, are targets of important drugs, consist of seven transmembrane domains, which are connected by intra- and extracellular loops [13]. Antagonists stabilize the inactive conformation of a GPCR while partial agonists or full agonists induce a conformational change of the GPCR from the inactive state into the active state [4]. GPCRs, activated by an agonist, interact in the intracellular part with a heterotrimeric $G$ protein, consisting of a $\alpha$-, $\beta$ - and $\gamma$-subunit, and the signal cascade is induced [5].

Weiland et al. (1979) were the first, who observed a thermodynamic discrimination of antagonists and agonists at the $\beta$-adrenergic receptor [6]. Subsequently, a large number of studies at different GPCRs were performed in order to determine thermodynamics of ligand binding: For example, addressing the $\beta_{2}$ adrenergic receptor [6-9], the serotonin 5 - $\mathrm{HT}_{1 \mathrm{~A}}$-receptor [10], the dopamine $\mathrm{D}_{2}$ receptor $[11,12]$, the histamine $\mathrm{H}_{1}$ receptor [13] and the histamine $\mathrm{H}_{3}$ receptor [14]. These receptors belong to the aminergic GPCRs of the GPCR family A [3]. Additionally, distinct studies at other GPCRs, for example at the adenosine $A_{1}, A_{2 A}$, $A_{2 B}$ and $A_{3}$ receptors [15-19], the cholecystokinin $C_{C C K}$ receptor [20] or cannabinoid $\mathrm{CB}_{1}$ and $\mathrm{CB}_{2}$ receptors [21] are performed. More references may be found in previous reviews [22-24] and a summary of most important data is shown in Table 1.

\section{Ligand-Receptor Binding in the Framework of Thermo- dynamics}

To distinguish between the properties of various ligand types and its receptors on the base of thermodynamic properties a correlation of the efficacy as a function of $\mathrm{pK}_{\mathrm{i}}$ values is to be done. As it is not possible up to now to predict both quantities completely with the help of theoretical based models, experimentally determined values of the mentioned variables may be used in order to establish rules for a thermodynamic based discrimination of antagonists, partial agonists and full agonists with respect to a given receptor. Having a look on the efficacy and the $\mathrm{pK}_{\mathrm{i}}$ values of ligands at a GPCR, it is impossible to decide on antagonism or agonism using the $\mathrm{pK}_{\mathrm{i}}$ values or equivalently the Gibbs reference energy for the ligand-receptor binding $\left(\Delta G^{\circ}\right)$ Taking into account the basic relation $[13,24]$ connecting the reference enthalpy for the ligand-receptor binding $\left(\Delta \mathrm{H}^{\circ}\right)$ and the reference entropy for the ligand-receptor binding $\left(\Delta S^{\circ}\right)$ with the quantity $\Delta G^{\circ}, T$ represents the absolute temperature,

$$
\Delta \mathrm{G}^{\mathrm{o}}=\Delta \mathrm{H}^{\mathrm{o}}-\mathrm{T} \cdot \Delta \mathrm{S}^{\mathrm{o}}
$$

an attempt may be made to distinguish between the various types of ligands on the base of the reference enthalpy and reference entropy. The experimental determination of $\Delta \mathrm{H}^{\circ}$ and $\Delta \mathrm{S}^{\circ}$ however is not a simple

*Corresponding author: Andrea Strasser, Department of Pharmaceutical/ Medicinal Chemistry II, Institute of Pharmacy, University of Regensburg, Universitätsstraße 31, D-93040 Regensburg, Germany, Tel: +49-941-943-4821; E-mail: andrea.strasser@chemie.uni-regensburg.de

Received September 18, 2012; Accepted October 19, 2012; Published October 22, 2012

Citation: Strasser A, Wittmann HJ (2012) Binding of Ligands to GPCRs - How Valid is a Thermodynamic Discrimination of Antagonists and Agonists? J Physic Chem Biophysic S1:001. doi:10.4172/2161-0398.S1-001

Copyright: (C) 2012 Strasser A, et al. This is an open-access article distributed under the terms of the Creative Commons Attribution License, which permits unrestricted use, distribution, and reproduction in any medium, provided the original author and source are credited. 


\begin{tabular}{|c|c|c|c|c|c|}
\hline GPCR & & no. of analyzed ligands & range for $\Delta \mathrm{H}^{\circ}\left(p, \mathrm{~T}_{\mathrm{o}}\right)[\mathrm{kJ} / \mathrm{mol}]$ & range for $-\mathrm{T} \Delta \mathbf{S}^{\circ}\left(\mathrm{p}, \mathrm{T}_{\mathrm{o}}\right)[\mathrm{kJ} / \mathrm{mol}]$ & ref. \\
\hline \multirow{2}{*}{$\beta$ Rs } & agonists & 13 & -143 to -17 & -8 to 93 & \multirow{2}{*}{23} \\
\hline & antagonists & 15 & -21 to 16 & -53 to -16 & \\
\hline \multirow{2}{*}{$\mathrm{hH}_{1} \mathrm{R}$} & agonists & 14 & -37.6 to 25.6 & -59.6 to 5.8 & \multirow{2}{*}{13} \\
\hline & antagonists & 10 & -1.5 to 80.2 & -120.7 to -42.4 & \\
\hline \multirow{2}{*}{$\mathrm{gpH}_{1} \mathrm{R}$} & agonists & 16 & -24.1 to 41.8 & -77.4 to -6.8 & \multirow{2}{*}{13} \\
\hline & antagonists & 8 & 1.0 to 98.8 & -145.9 to -49.2 & \\
\hline \multirow{2}{*}{$\mathrm{gpH}_{3} \mathrm{R}$} & agonists & 7 & $\begin{array}{l}6.4 \text { to } 44.5 \text { (buffer } A) \\
-9.2 \text { to } 15.1 \text { (buffer } A_{C a} \text { ) }\end{array}$ & $\begin{array}{l}-92.0 \text { to }-58.3 \text { (buffer } A \text { ), } \\
-60.7 \text { to }-38.1 \text { (buffer } A_{C a} \text { ) }\end{array}$ & \multirow{2}{*}{14} \\
\hline & antagonists & 3 & $\begin{array}{l}-34.1 \text { to }-22.9 \text { (buffer } A \text { ), } \\
-40.7 \text { to }-10.5 \text { (buffer } A_{C a} \text { ) }\end{array}$ & $\begin{array}{l}-35.1 \text { to }-16.9 \text { (buffer } A \text { ), } \\
-43.8 \text { to }-10.3 \text { (buffer } A_{\mathrm{Ca}} \text { ) }\end{array}$ & \\
\hline \multirow{2}{*}{$\mathrm{D}_{2} \mathrm{R}$} & agonists & 11 & -224 to 90 & -136 to 176 & \multirow{2}{*}{23} \\
\hline & antagonists & 22 & -89 to 59 & -105 to 107 & \\
\hline \multirow[t]{2}{*}{ sheep $D_{2} R$} & agonists & 1 & $\begin{array}{l}90.0 \text { (high affinity); } \\
54.4 \text { (low affinity) }\end{array}$ & $\begin{array}{l}-136.0 \text { (high affinity); } \\
-91.1 \text { (low affinity) }\end{array}$ & \multirow[t]{2}{*}{12} \\
\hline & antagonists & 3 & 14.6 to 58.6 & -107.3 to -72.4 & \\
\hline \multirow{2}{*}{$\mathrm{r} 5-\mathrm{HT}_{1 \mathrm{~A}} \mathrm{R}$} & agonists & 8 & -65 to 58 & -109 to 20 & \multirow{2}{*}{10} \\
\hline & antagonists & 7 & 15 to 80 & -109 to -47 & \\
\hline \multirow{2}{*}{$\mathrm{hCB}_{1} \mathrm{R}$} & agonists & 5 & 17 to 59 & -108 to -64 & \multirow{2}{*}{ [21] } \\
\hline & antagonists & 3 & -52 to -26 & -11 to 4 & \\
\hline \multirow{2}{*}{$\mathrm{hCB}_{2} \mathrm{R}$} & agonists & 5 & 27 to 48 & -89 to -70 & \multirow{2}{*}{ [21] } \\
\hline & antagonists & 3 & -19 to -17 & -22 to -13 & \\
\hline \multirow{2}{*}{$A_{1} R$} & agonists & 6 & 19 to 46 & -106 to -61 & \multirow{2}{*}{ [18] } \\
\hline & antagonists & 6 & -37 to -20 & -18 to 7 & \\
\hline \multirow{2}{*}{$A_{2 A} R$} & agonists & 6 & 7 to 50 & -83 to -53 & \multirow{2}{*}{ [18] } \\
\hline & antagonists & 6 & -45 to -7 & -28 to -4 & \\
\hline \multirow{2}{*}{$A_{2 B} R$} & agonists & 6 & 7 to 23 & -65 to -37 & \multirow{2}{*}{ [18] } \\
\hline & antagonists & 6 & -40 to -20 & -27 to -3 & \\
\hline \multirow{2}{*}{$\mathrm{A}_{3} \mathrm{R}$} & agonists & 6 & 21 to 67 & -122 to -67 & \multirow{2}{*}{ [18] } \\
\hline & antagonists & 5 & -52 to -9 & -24 to -5 & \\
\hline
\end{tabular}

Table 1: Summary of thermodynamics studies, addressing GPCRs. This table gives a summary of most important data, available in literature. However, within this table, different assay conditions or species for data regarding one distinct receptor are not taken into account in all cases. For detailed information, the reader is referred to the mentioned references.

task because it is to be assured that the measurement exactly reflects the properties of the association process and may not be influenced by secondary effects. In this context, the assay conditions may play an important role, as discussed in more detail in the next paragraph.

\section{Dependence of Thermodynamic Parameters from Assay Conditions}

The thermodynamic analysis of ligand binding to the guinea-pig histamine $\mathrm{H}_{3}$ receptor was performed at two different assay conditions [14]. Within the first series HEPES-NaOH buffer (buffer A) was used, whereas in a second series HEPES-NaOH buffer, containing $300 \mathrm{mM}$ $\mathrm{CaCl}_{2}$ (buffer $\mathrm{A}_{\mathrm{Ca}}$ ) was used. The binding of agonists in buffer $\mathrm{A}$ to $\mathrm{gpH}_{3} \mathrm{R}$ were entropy driven, whereas the binding of antagonists was enthalpy- and entropy-driven. In contrast, the binding of both, agonists (except immepip) and antagonists, was enthalpy- and entropy-driven in buffer $\mathrm{A}_{\mathrm{Ca}}$. However, for the agonists the entropic term was much more negative, compared to the enthalpic term. Thus, thermodynamic parameters, concerning the ligand binding process, determined at different assay conditions, have to be handled separately.

\section{Thermodynamics of Ligand Binding to GPCRs - Terms, Which Have to be Taken into Account}

In case that a ligand binds to a GPCR several terms have to be taken into account. First of all, the solvation shell of the ligand has to be destroyed, thus, enthalpy and entropy of ligand desolvation has to be taken into account. However, molecular dynamic simulations suggest that water molecules in the binding pocket may mediate the interaction between ligand and receptor $[25,26]$. Furthermore, the number of water molecules present in the binding pocket may differ between different ligands and different GPCRs. Here, the polar/non-polar moieties of the ligand may play a very important role, independent, if a ligand acts as an antagonist or agonist. The second important term arises by the interaction of the ligand with the binding pocket. Third, several studies suggest ligand-dependent conformations of GPCRs. Of course, different receptor conformations may exhibit differences with regard to enthalpic and entropic terms. Thus, it may be suggested that especially antagonist-stabilized (inactive conformation) and agoniststabilized (active conformation) receptor conformations have large differences in enthalpy and entropy.

\section{Species Differences in Thermodynamics of Ligand Binding}

For the histamine $\mathrm{H}_{1}$ receptor, an extensive study, addressing the thermodynamics of ligand binding was performed at the human $\mathrm{H}_{1} \mathrm{R}$ and guinea-pig $\mathrm{H}_{1} \mathrm{R}$ (Figure 1) [13]. In general, the data reveals species differences, in dependence of the ligand, for the thermodynamic properties $\Delta \mathrm{H}^{\circ}\left(\mathrm{p}, \mathrm{T}_{\mathrm{o}}\right),-\mathrm{T} \Delta \mathrm{S}^{\circ}\left(\mathrm{p}, \mathrm{T}_{\mathrm{o}}\right)$ and $\Delta \mathrm{G}^{\circ}\left(\mathrm{p}, \mathrm{T}_{\mathrm{o}}\right)$. For the tricyclic compounds amitryptiline (Figure 1, cpd 5), mianserin (Figure 1, cpd 6) and clozapine (Figure 1, cpd 7) no significant species differences were found in affinity at a temperature of $293.15 \mathrm{~K}$. But significant species differences were determined with regard to $\Delta \mathrm{H}^{\circ}\left(\mathrm{p}, \mathrm{T}_{\mathrm{o}}\right)$ and $-\mathrm{T} \Delta \mathrm{S}^{\circ}\left(\mathrm{p}, \mathrm{T}_{\mathrm{o}}\right)$. Thus, species differences often will be revealed not until considering enthalpy and entropy. Furthermore, for an efficient development of new, highly affine drugs, it will be very useful to include not only $\mathrm{pK}_{\mathrm{i}}$-values, which correlate with $\Delta \mathrm{G}^{\mathrm{o}}\left(\mathrm{p}, \mathrm{T}_{\mathrm{o}}\right)$ into adequate structure- 
activity-studies, but also enthalpic and entropic terms of the ligand binding process [27].

\section{Influence of the Target onto Thermodynamic Param- eters for Ligand Binding}

Mianserin for example was studied thermodynamically at the human and guinea-pig histamine $\mathrm{H}_{1}$ receptor [13] and at the rat serotonin 5- $\mathrm{HT}_{1 \mathrm{~A}}$ receptor [10]. At the $\mathrm{hH}_{1} \mathrm{R}$, the enthalpy for ligand binding is $32.6 \mathrm{~kJ} / \mathrm{mol}$, whereas it is significantly higher at $\mathrm{gpH}_{1} \mathrm{R}$ with $72.2 \mathrm{~kJ} / \mathrm{mol}$. The entropic term $\left(-\mathrm{T} \Delta \mathrm{S}^{\circ}\left(\mathrm{p}, \mathrm{T}_{\mathrm{o}}\right)\right)$ for binding of mianserin to $\mathrm{hH}_{1} \mathrm{R}$ is $-82.0 \mathrm{~kJ} / \mathrm{mol}$ and to $\mathrm{gpH}_{1} \mathrm{R}-121.7 \mathrm{~kJ} / \mathrm{mol}$. But in contrast the corresponding terms of the Gibbs energy of ligand binding given by $-49.4 \mathrm{~kJ} / \mathrm{mol}$ at $\mathrm{hH}_{1} \mathrm{R}$ and $-49.5 \mathrm{~kJ} / \mathrm{mol}$ at $\mathrm{gpH}_{1} \mathrm{R}$ are nearly equal. The enthalpic term for binding of mianserin to the rat $5-\mathrm{HT}_{1 \mathrm{~A}} \mathrm{R}$ is $15 \mathrm{~kJ} /$ $\mathrm{mol}$ and the entropic term is $-46.5 \mathrm{~kJ} / \mathrm{mol}$. The Gibbs energy of binding of mianserin to the rat $5-\mathrm{HT}_{1 \mathrm{~A}} \mathrm{R}$ is $-31.5 \mathrm{~kJ} / \mathrm{mol}$. The thermodynamic parameters of one ligand at different targets - not only different species, but especially different GPCRs - are very interesting, because the contribution of desolvation of the ligands should be equal in this case. Thus, only the GPCR and GPCR-ligand-complex has influence onto the observed thermodynamic parameters. Furthermore, mianserin acts as an antagonist at $\mathrm{hH}_{1} \mathrm{R}$ and $\mathrm{gpH}_{1} \mathrm{R}$, as well as at the rat $5-\mathrm{HT}_{1 \mathrm{~A}} \mathrm{R}$. Thus, the mentioned receptors are suggested to be stabilized in its inactive conformation and no conformational change due to receptor activation will take place. A comparison of these data show in general, that the binding of mianserin to $\mathrm{hH}_{1} \mathrm{R}, \mathrm{gpH}_{1} \mathrm{R}$ and rat $5-\mathrm{HT}_{1 \mathrm{~A}} \mathrm{R}$ is strongly entropy driven, indicating an increase of flexibility during the association process. On the other hand the enthalpic term is positive at the three GPCRs reflecting the fact that the ligand receptor complex is not favoured energetically. Nevertheless the corresponding Gibbs energy exhibits negative values in all three cases, in which mianserin shows equal affinity to $\mathrm{hH}_{1} \mathrm{R}$ and $\mathrm{gpH}_{1} \mathrm{R}$ whereas the affinity to rat $5-\mathrm{HT}_{1 \mathrm{~A}} \mathrm{R}$ is significantly smaller (Figure 2 ).
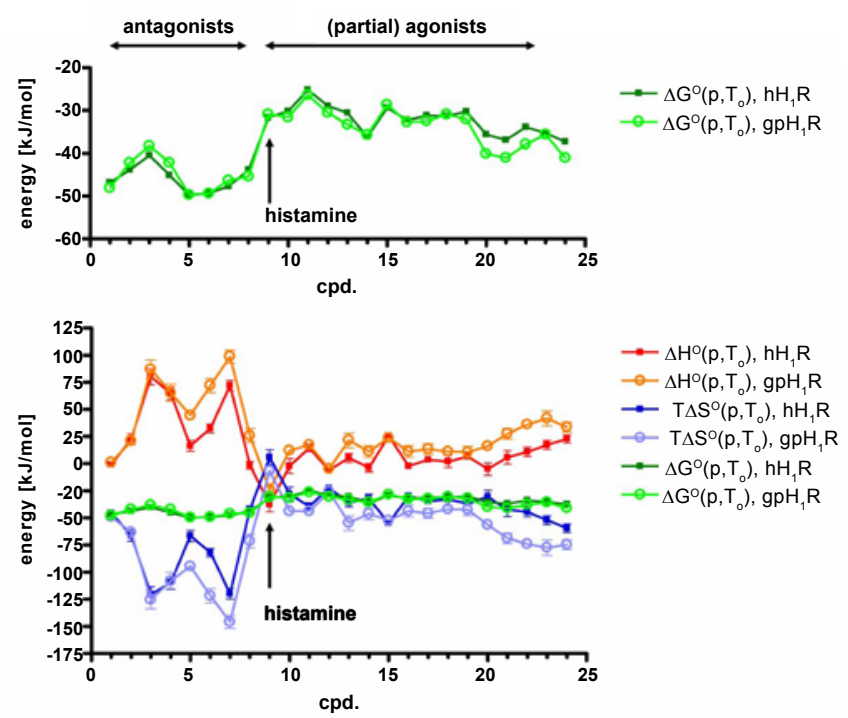

Figure 1: Thermodynamic Parameters for Binding of Antagonists and (Partial) Agonists to $\mathrm{hH}, \mathrm{R}$ and $\mathrm{gpH} \mathbf{R}$ [13]. Antagonists: 1, mepyramine; 2, diphenhydramine; 3, fexofenadine; 4, terfenadine; 5, amitriptyline; 6 mianserin; $\mathbf{7}$, clozapine; 8 , chlorpromazine. (Partial) agonists: 9 , histamine; 10-13, phenylhistamines; 14-19, histaprodifens; 20 , suprahistaprodifen; 21 23, phenoprodifens; 24, dimeric histaprodifen.

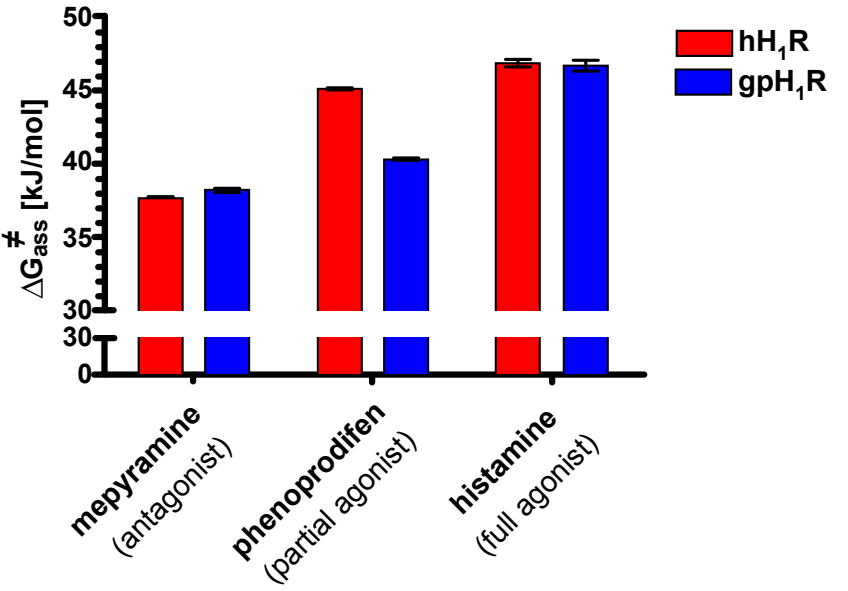

Figure 2: Gibbs Energy of Activation for Association of Ligands to $\mathbf{h} \mathbf{H}_{1} \mathbf{R}$ and $\mathbf{g p H} \mathbf{R}$. The data are calculated using the Eyring equation and the rate constants for association [34].

\section{Chiral Compounds and Thermodynamics of Ligand Binding}

At the histamine $H_{1}$ receptor [13], and the adrenergic $\beta_{2}$ receptor $\left(h \beta_{2} \mathrm{R}\right)$, the enthalpy and entropy of ligand binding was studied for chiral compounds, including both enantiomers $[8,9]$. As mentioned above, the enthalpy and entropy of desolvation of the ligand is suggested to have an influence onto enthalpy and entropy of ligand binding to a target. For enantiomers, the enthalpic and entropic terms of desolvation are identical. Thus, enantiomers are very interesting compounds for studying thermodynamics, since the observed enthalpy and entropy of ligand binding reflects only the GPCR or GPCR-ligand complex, but the desolvation of the ligand does not account for direct comparison of the thermodynamic properties for enantiomers. At the $\mathrm{hH}_{1} \mathrm{R}$ and $\mathrm{gpH}_{1} \mathrm{R}$, chiral phenylhistamines and phenoprodifens were studied [13]. The chiral phenylhistamines act as partial agonists at $\mathrm{hH}_{1} \mathrm{R}$ and $\mathrm{gpH}_{1} \mathrm{R}$. For the $(R)$-phenylhistamine (exact: $(R)$-1-(2-phenyl- $1 H$ imidazol-4-yl)propan-2-amine), a positive enthalpy of binding was found at $\mathrm{hH}_{1} \mathrm{R}$ and $\mathrm{gpH}_{1} \mathrm{R}$ and the entropic term $-\mathrm{T} \Delta \mathrm{S}^{\circ}$ is in negative stage. In contrast, for the $(S)$-phenylhistamin (exact: $(S)$-1-(2-phenyl$1 \mathrm{H}$-imidazol-4-yl)propan-2-amine), a negative enthalpy of binding and entropy of binding $(-\mathrm{T} \Delta \mathrm{S})$ was observed at $\mathrm{hH}_{1} \mathrm{R}$ and $\mathrm{gpH}_{1} \mathrm{R}$. Thus, the binding of $(R)$-phenylhistamine is entropy-driven, whereas the binding of the $(S)$-phenylhistamine is entropy- and slightly enthalpydriven. The efficacies between the $(R)$ - and $(S)$-phenylhistamine are not significantly different at $\mathrm{hH}_{1} \mathrm{R}\left(\mathrm{E}_{\max },(R): 0.21,(S): 0.23\right)$ or $\mathrm{gpH}_{1} \mathrm{R}\left(\mathrm{E}_{\max }\right.$ $(R): 0.51,(S): 0.78)$ [28]. Thus, it may be concluded, that the differences in enthalpy and entropy between the $(R)$ - and $(S)$-phenylhistamine can be related with the different binding conformation of both ligands due to the difference induced by the center of chirality. This may lead to different interactions between the ligand and the receptor. Additionally, a different number of water molecules may be located in the binding pocket and act as mediator of interaction between the ligand and the receptor. The interpretation of the data with regard to the chiral phenoprodifens is more complicated, since the phenoprodifens are suggested to bind in two different orientations into the binding pocket of the histamine $\mathrm{H}_{1}$ receptor $[13,28]$. The $(R)$ - and $(S)$-phenoprodifen (exact: $\quad(R)-N$-(2-(2-(3,3-diphenylpropyl)-1H-imidazol-4-yl)ethyl-1(2-phenyl-1H-imidazol-4-yl)propan-2-amine and (S)-N-(2-(2-(3,3- 
diphenylpropyl)-1H-imidazol-4-yl)ethyl-1-(2-phenyl- $1 H$-imidazol4-yl)propan-2-amine) act as antagonist at $\mathrm{hH}_{1} \mathrm{R}\left(\mathrm{E}_{\max },(\mathrm{R}): 0.05,{ }_{\mathrm{s}}\right)$ : $0.04)$ and as partial agonist at $\mathrm{gpH}_{1} \mathrm{R}\left(\mathrm{E}_{\max },(\mathrm{R}): 0.60,(S): 0.23\right)$ [28]. For $\mathrm{hH}_{1} \mathrm{R}$ or $\mathrm{gpH}_{1} \mathrm{R}$, no large differences for the enthalpic and entropic term of ligand binding were observed between the $(R)$ - and $(S)$ phenoprodifen [13]. However, within this study, it was the first time, that a temperature-dependent QSAR-study was used to predict the enthalpic- and entropic-term for both orientations of the $(R)$ - and $(S)$ phenoprodifen. These data reveal large species differences in enthalpic and entropic terms for orientation 1, but rather no species differences for orientation 2 of the chiral phenoprodifen derivatives [13]. Furthermore, this prediction of the thermodynamic data suggests, that the differences in enthalpic and entropic terms may be related with the preferred binding mode of the chiral phenoprodifen derivatives [13]. Similar studies were performed for four fenoterol stereoisomers at the adrenergic $\beta_{2}$ receptor [8]. Since the studied fenoterol stereoisomers include two enantomeric pairs: $\left(S, S^{\prime}\right)-\left(R, R^{\prime}\right)$ and $\left(S, R^{\prime}\right)-\left(R, S^{\prime}\right)$, the resulting data of the corresponding enantiomers can be directly related the $\beta_{2} \mathrm{R}$-fenoterol-complex and desolvation terms have no influence. The observed differences in enthalpy and entropy of fenoterol binding to the $\beta_{2} \mathrm{R}$ may represent differences in binding mode of the ligand, as well as differences in number of water molecules in the binding pocket. Furthermore, since the fenoterol derivatives act as full agonists at the $\beta_{2} \mathrm{R}$, different conformations of the $\beta_{2} \mathrm{R}$ have to be taken into account. The authors relate the chirality of the carbon atom containing the $\beta-\mathrm{OH}$-moiety as a key factor, with regard to enthalpy- or entropydriven binding process of a fenoterol stereoisomer [8]. R-configuration leads to an entropy-driven binding process, whereas for S-configuration an enthalpy-driven binding process was observed.

\section{Contributions of Molecular Modelling Studies}

Several molecular modelling methods allow to predict thermodynamic properties. Unfortunately, in most cases the prediction is restricted to enthalpic terms. However, some methods, like the thermodynamic integration method $[29,30]$ allow calculation of the Gibbs energy of solvation [31]. The central process responsible for discrimination between antagonists and (partial) agonists is the receptor activation defined by the Gibbs energy of activation reflecting the structural change of the empty receptor and the state where the agonist is removed from the activated receptor without allowing to relax its structure. As this process is not subject to experimental methods, molecular modelling studies may be used to investigate this single process. Unfortunately the calculations used by modelling techniques are based entirely on energetic terms and therefore lacks entropic contributions in describing states or processes, so the changes in Gibbs energy during a process may not calculated directly. To get such a quantity, it is necessary to make use of specific methods like the thermodynamic integration method $[29,30]$. The equation determining the reference Gibbs energy of receptor activation $\Delta G^{\circ}\left(R \rightarrow R^{*}\right)$ from a thermodynamic point of view reads as $\Delta G^{\circ}\left(R \rightarrow R^{\star}\right)=G^{\circ}\left(R^{\star}\right)-G^{\circ}(R)$, where $G^{\circ}\left(R^{\star}\right)$ represents the reference Gibbs energy of the active, unrelaxed receptor without ligand and $\mathrm{G}^{\circ}(\mathrm{R})$ represents the reference Gibbs energy of the inactive receptor without ligand. The derivation of this relation and the corresponding integration method itself, which may be extended to the estimation of all the effects already mentioned, is given in the literature $[26,29,30]$.

\section{From Binding Kinetics to Thermodynamic Quantities}

Considering a simple model for the ligand-receptor association
$\mathrm{L}+\mathrm{R} \rightleftharpoons \mathrm{LR}$ determining the rate constants for association $\left(\mathrm{k}_{1}\right)$ and dissociation $\left(\mathrm{k}_{-1}\right)$ provides an alternative method to obtain thermodynamic quantities. In this context, the constant for ligandreceptor binding $\mathrm{K}$ is given by $\mathrm{k}_{1} / \mathrm{k}_{-1}$. Furthermore, binding kinetics should be used to ensure the state of chemical equilibrium, which is necessary for a direct determination of thermodynamic quantities as discussed in the foregoing paragraphs. The Eyring equation relates the rate constants to the Gibbs energy of activation $\Delta G \neq$ for the chemical process of association and dissociation $[32,33]$.

In case of $\mathrm{hH}_{1} \mathrm{R}$ and $\mathrm{gpH}_{1} \mathrm{R}$, an antagonist (mepyramine), a partial agonist (phenoprodifen) and a full agonist (histamine) were analyzed concerning the rate constants of association and dissociation at 293.15 $\mathrm{K}$ [34]. Within the series antagonist $\rightarrow$ partial agonist $\rightarrow$ full agonist the Gibbs energy of activation for the association process increases at $\mathrm{hH}_{1} \mathrm{R}$ and $\mathrm{gpH}_{1} \mathrm{R}$. Thus, in addition to a "thermodynamic discrimination" a "kinetic discrimination" of antagonist, partial agonist and full agonists may be considered. Antagonists stabilize the inactive conformation of a GPCR, without inducing a conformational change of the GPCR. In contrast, partial or full agonists induce a conformational change [4]. Thus, a larger Gibss energy of activation for the binding of agonists, compared to antagonists sounds reasonable. Moreover, a temperature dependent measurement of rate constants followed by the calculation of the Gibbs energy of activation, leads to the enthalpy and entropy of activation by the same machinery as in pure thermodynamics. For example, at the guinea-pig histamine $\mathrm{H}_{3}$ receptor, the rate constants for association and dissociation of $\left[{ }^{3} \mathrm{H}\right]$ clobenpropit was determined in dependence of temperature [14]. Based on these rate constants, the Gibbs energy, enthalpy and entropy of activation for the association process can be calculated (Figure 3, Table 2). Taking into account the experimental errors based on the data in literature [14], the entropy term of activation is zero. Thus, the reaction rates of association and dissociation are only determined by enthalpy (Table 2). For the association process the enthalpy is about $86 \mathrm{~kJ} / \mathrm{mol}$ and for the dissociation process about $105 \mathrm{~kJ} / \mathrm{mol}$ (Table 2). But to establish the kinetic discrimination as a useful method to distinguish between the various types of ligands an intensive analysis of more data sets has to be done.

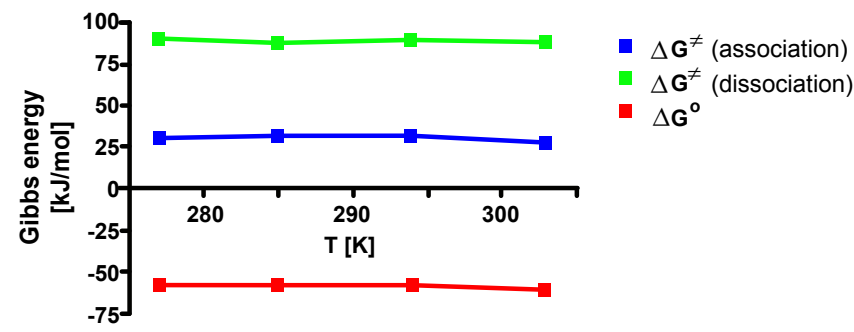

Figure 3: Gibbs Energy of Activation for the Association or Dissociation and $\Delta \mathbf{G}^{\circ}$ of $\left.{ }^{3} \mathrm{H}\right]$ Clobenprobit to $\mathrm{gpH}_{3} \mathrm{R}$ as Function of Temperature. The data are calculated using the Eyring equation and the corresponding rate constants for association or dissociation and $\mathrm{pK}_{\mathrm{i}}$ values given in literature [14]

\begin{tabular}{|l|l|l|l|l|}
\hline & $\begin{array}{l}\Delta \mathbf{G}^{\neq} \\
{[\mathbf{k J} / \mathbf{m o l}]}\end{array}$ & $\begin{array}{l}\Delta \mathbf{H}^{\neq} \\
{[\mathbf{k J} / \mathbf{m o l}]}\end{array}$ & $\begin{array}{l}\Delta \mathbf{S}^{\neq} \\
{[\mathbf{k J} /(\mathbf{m o l ~ K})]}\end{array}$ & $\begin{array}{l}\Delta \mathbf{C}_{\mathrm{p}}^{\neq} \\
{[\mathbf{k J} /(\mathbf{m o l ~ K})]}\end{array}$ \\
\hline association & 27 & 86 & 0.2 & 9 \\
\hline dissociation & 76 & 105 & 0.1 & 1 \\
\hline
\end{tabular}

Table 2: Quantities of activation at a temperature $293.15 \mathrm{~K}$ for $\left[{ }^{3} \mathrm{H}\right]$ clobenprobit at $\mathbf{g p H}_{3} \mathbf{R}$. The presented data are based on table 2 given in [14]. 


\section{Thermodynamic Discrimination of Antagonists and Agonist - A Critical View}

Within several studies, a thermodynamic discrimination of antagonists and agonists was found [22-24]. But for a distinct number of GPCRs, a thermodynamic discrimination of antagonists and agonists could not be shown [22-24]. It is very important, that such thermodynamic studies are performed very carefully. First, it is absolutely necessary to include a large number of ligands with large structural variety. In this context, it is worth to look onto the results with regard to the histamine $\mathrm{H}_{1}$ receptor [13]. In the corresponding study, eight antagonists and sixteen (partial) agonists were included. At $\mathrm{gpH}_{1} \mathrm{R}$, the antagonists showed an enthalpy of binding in the range from $1.0 \mathrm{~kJ} / \mathrm{mol}$ up to $98.8 \mathrm{~kJ} / \mathrm{mol}$. However, the antagonist can be divided into two groups: Mepyramine, diphenhydramine, amitriptyline and chlorpromazine (first group) and fexofenadine, terfenadine, mianserin and clozapine (second group). For the first antagonistic group, the enthalpy of binding was found in the range from $1.0 \mathrm{~kJ} / \mathrm{mol}$ up to 44.6 $\mathrm{kJ} / \mathrm{mol}$, whereas for the second antagonistic group, the enthalpy of binding was found in the range from $65.3 \mathrm{~kJ} / \mathrm{mol}$ up to $98.8 \mathrm{~kJ} / \mathrm{mol}$. The antagonists of each of the mentioned groups have one characteristic: In the first group, the amine moiety is a secondary amine, whereas in the second group, the amine moiety is tertiary. For the (partial) agonists, the enthalpy of binding was found in a range from $-24.1 \mathrm{~kJ} / \mathrm{mol}$ up to $41.8 \mathrm{~kJ} / \mathrm{mol}$. The amine moieties in all (partial) agonists of the study are secondary. Now, if one includes only antagonists of the first group and the (partial) agonists into the study, no thermodynamic discrimination would be found. In the contrary case, where only antagonists of the second group and the (partial) agonists would be included into the study, thermodynamic discrimination would be identified. However, the concept of ligand structure, like secondary or tertiary amine moieties, as just explained for the $\mathrm{H}_{1} \mathrm{R}$, does not work in general. In this context, the rat $5-\mathrm{HT}_{1 \mathrm{~A}} \mathrm{R}$ has to be mentioned [10]. Within this study, the ligands can be divided in antagonists and agonists with secondary and tertiary amines in each group: antagonists with a secondary amine moiety: $S(-)$-propranolol, $S(-)$-pindolol and alprenolol; antagonists with a tertiary amine moiety: NAN-190, mianserin, cyproheptadine and ritanserin; agonists with a secondary amine moiety: 8-OH-DPAT, serotonin, mexamine, DP-5-CT; agonists with a tertiary amine moiety: TFMPP, 2-MPP, m-CPP and CGS-12066B. The enthalpic (entropic) terms for antagonists with a secondary amine in the range from $22 \mathrm{~kJ} /$ $\mathrm{mol}$ to $48 \mathrm{~kJ} / \mathrm{mol}(-88.8 \mathrm{~kJ} / \mathrm{mol}$ to $-61.4 \mathrm{~kJ} / \mathrm{mol})$, for agonists with a secondary amine are in the range from $-65 \mathrm{~kJ} / \mathrm{mol}$ to $58 \mathrm{~kJ} / \mathrm{mol}(-109.1$ $\mathrm{kJ} / \mathrm{mol}$ to $20.0 \mathrm{~kJ} / \mathrm{mol}$ ), for antagonists with a tertiary amine in the range from $15 \mathrm{~kJ} / \mathrm{mol}$ to $80 \mathrm{~kJ} / \mathrm{mol}(-109.1 \mathrm{~kJ} / \mathrm{mol}$ to $-46.5 \mathrm{~kJ} / \mathrm{mol})$ and for agonists with a tertiary amine in the range from $28 \mathrm{~kJ} / \mathrm{mol}$ to $46 \mathrm{~kJ} /$ $\mathrm{mol}(-84.4 \mathrm{~kJ} / \mathrm{mol}$ to $-68.6 \mathrm{~kJ} / \mathrm{mol})$. Firstly, these data suggest that there is no thermodynamic discrimination between agonists and antagonists at rat $5-\mathrm{HT}_{1 \mathrm{~A}} \mathrm{R}$. Secondly, the "discrimination" between antagonists with a secondary and tertiary amine moiety, as found at $H_{1} R$, is not valid for rat $5-\mathrm{HT}_{1 \mathrm{~A}} \mathrm{R}$. It is remarkable, that the endogeneous ligand serotonin as well as mexapine - mexapine exhibits a high structural similarity to serotonin - differ significantly in their thermodynamic properties, compared to the other analyzed ligands at rat $5-\mathrm{HT}_{1 \mathrm{~A}} \mathrm{R}$. Furthermore, only for mexapine and the endogenous serotonin the enthalpy of binding is negative. Interestingly, the enthalpy of binding of the endogeneous histamine to $\mathrm{hH}_{1} \mathrm{R}$ or $\mathrm{gpH}_{1} \mathrm{R}$ is significantly negative ( $\mathrm{hH}_{1} \mathrm{R}:-37.6 \mathrm{~kJ} / \mathrm{mol}$, gpH $\left.\mathrm{R}_{1}-24.1 \mathrm{~kJ} / \mathrm{mol}\right)$, compared to other ligands. Thus, it has to be proved by further experimental studies, if the enthalpy of binding of full agonists to biogenic amine receptors is negative in general.
Taken into account all thermodynamic studies addressing GPCRs so far, a strict "thermodynamic discrimination" between antagonists and agonists could not be observed for all GPCRs. However, for the $\mathrm{hH}_{1} \mathrm{R}$ and $\mathrm{gpH}_{1} \mathrm{R}$, a correlation of the enthalpic or entropic terms for ligand binding with the experimentally determined efficacy is presented (Figure 4) $[13,28,35]$. These data show that there is no clear "thermodynamic discrimination" of antagonists and agonists at $\mathrm{hH}_{1} \mathrm{R}$ and $\mathrm{gpH}_{1} \mathrm{R}$. However, the following tendency can be observed: With increasing efficacy $\left(\mathrm{E}_{\max }\right)$ in the series antagonist $\left(\mathrm{E}_{\max }=0\right) \rightarrow$ partial agonist $\left(0<\mathrm{E}_{\max }<100\right) \rightarrow$ full agonist $\left(\mathrm{E}_{\max }=100\right)$, the enthalpic term decreases, whereas the entropic term increases (Figure 4 ). These findings may indicate that the term "thermodynamic discrimination" between antagonists and agonists should be extended to "thermodynamic discrimination" between antagonists, partial agonists and full agonists. Within the thermodynamic studies addressing GPCRs, available in literature so far, partial agonists and full agonists were not discriminated. Moreover, it has to be taken into account that the
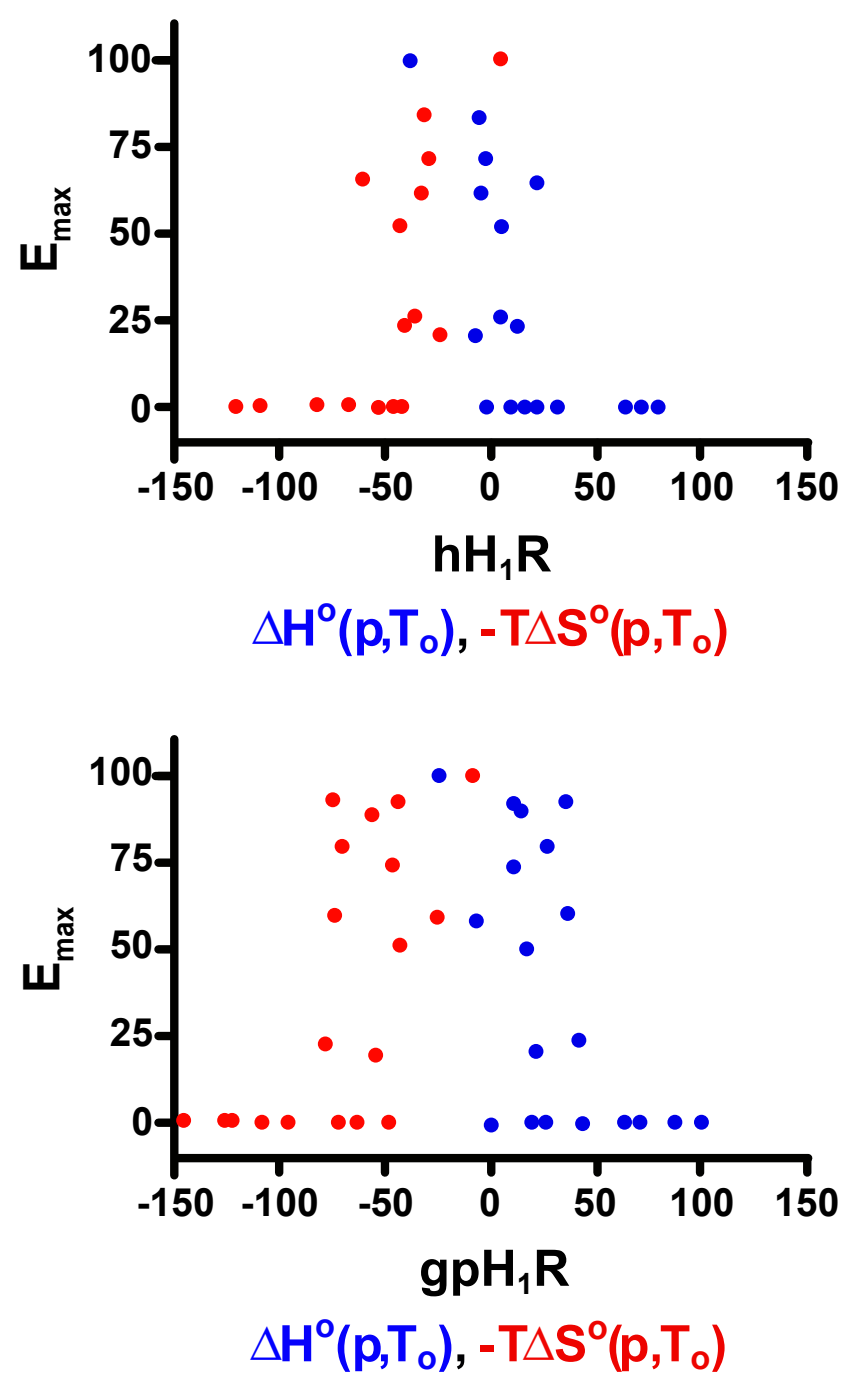

Figure 4: Correlation of the Enthalpic and Entropic Term of Ligand Binding with the Efficacy for $\mathrm{hH}_{1} \mathbf{R}$ and $\mathrm{gpH}_{1} \mathbf{R}$. The original data can be found in literature $[13,28,35]$. The efficacies, represented as $E_{\max }$ are given in $\%$. The efficacy of the full agonist histamine is 
Citation: Strasser A, Wittmann HJ (2012) Binding of Ligands to GPCRs - How Valid is a Thermodynamic Discrimination of Antagonists and Agonists? J Physic Chem Biophysic S1:001. doi:10.4172/2161-0398.S1-001

competition binding assays - used so far for determination of enthalpy and entropy of ligand binding - and functional assays to determine efficacy, differ with regard to assay conditions, like buffer, other reagents or even expression system. This may be an explanation for the lack of thermodynamic discrimination in some studies. As discussed above, the desolvation energy of the ligand for example, will play an important role and may mask a thermodynamic discrimination. In order to address this fact, the corresponding desolvation energies have to be determined experimentally or predicted via molecular modelling studies. Furthermore, an exact description of the binding mode of ligands in the binding pocket, including internal water and ions is necessary. Taking into account the possibility of a kinetic control of the binding process of the ligand to the receptor, and conformational change of the receptor, in case of an agonist, the reaction path for association and dissociation including the corresponding transition states, has to be modelled in a realistic manner. However, it will be worthwhile, to perform much more comprehensive studies in the experimental and modelling field, in order to investigate, if the concept of "thermodynamic and kinetic discrimination of antagonists, partial agonists and full agonists" is valid.

\section{References}

1. Wise A, Gearing K, Rees S (2002) Target validation of G-protein coupled receptors. Drug Discov Today 7: 235-246.

2. Kristiansen K (2004) Molecular mechanisms of ligand binding, signalling, and regulation within the superfamily of G-protein-coupled receptors: molecular modelling and mutagenesis approaches to receptor structure and function. Pharmacol Ther 103: 21-80.

3. Foord SM, Bonner TI, Neubig RR, Rosser EM, Pin JP, et al. (2005) International union of pharmacology. XLVI. G protein-coupled receptor list. Pharmacol Rev 57: 279-288.

4. Kobilka BK, Deupi X (2007) Conformational complexity of G-protein-coupled receptors. Trends Pharmacol Sci 28: 397-406.

5. Oldham WM, Hamm HE (2006) Structural basis of function in heterotrimeric G proteins. Q Rev Biophys 39: 117-166.

6. Weiland GA, Minneman KP, Molinoff PB (1979) Fundamental difference between the molecular interactions of agonists and antagonists with the $\beta$-adrenergic receptor. Nature 281: 114-117.

7. Contreras ML, Wolfe BB, Molinoff PB (1986) Thermodynamic properties of agonist interactions with the beta adrenergic receptor-coupled adenylate cyclase system. I. High- and low-affinity states of agonist binding to membranebound beta adrenergic receptors. J Pharmacol Exp Ther 237: 154-164.

8. Jozwiak K, Toll L, Jimenez L, Woo AY, Xiao RP, et al. (2010) The effect of stereochemistry on the thermodynamic characteristics of the binding of fenoterol stereoisomers to the $\beta_{2}$-adrenoceptor. Biochem Pharmacol 79: 1610 1615

9. Toll L, Pajak K, Plazinska A, Jozwiak K, Jimenez L, et al. (2012) Thermodynamic and docking of agonists to the $\beta_{2}$-Adrenoceptor determined using $\left[{ }^{3} \mathrm{H}\right]\left(R, R^{\prime}\right)-4$ Methoxyfenoterol as the marker ligand. Mol Pharmacol 81: 846-854.

10. Dalpiaz A, Borea PA, Gessi S, Gilli G (1996) Binding thermodynamics of 5-HT receptor ligands. Eur J Pharmacol 312: 107-114.

11. Kilpatrick GJ, el Tayar N, van d Waterbeemd H, Jenner P, Testa B, et al. (1986) The thermodynamics of agonist and antagonist binding to dopamine $D_{2}$ receptors. Mol Pharmacol 30: 226-234.

12. Duarte EP, Oliveira CR, Carvalho AP (1988) Thermodynamic analysis of antagonists and agonist interactions with dopamine receptors. Eur J Pharmacol 147: 227-239.

13. Wittmann HJ, Seifert R, Strasser A (2009) Contribution of binding enthalpy and entropy to affinity of antagonist and agonist binding at human and guinea pig histamine $\mathrm{H}_{1}$-receptor. Mol Pharmacol 76: 25-37.

14. Harper EA, Black JW (2007) Histamine $\mathrm{H}_{3}$-receptor agonists and imidazolbased $\mathrm{H}_{3}$-receptor antagonists can be thermodynamically discriminated. $\mathrm{Br} J$ Pharmacol 151: 504-517.
15. Dalpiaz A, Townsend-Nicholson A, Beukers MW, Schofield PR, ljzerman AP (1998) Thermodynamics of full agonist, partial agonist, and antagonist binding to wild-type and mutant adenosine $A_{1}$ receptors. Biochem Pharmacol 56: 14371445.

16. Heitman LH, Mulder-Krieger T, Spanjersberg RF, von Frijtag Drabbe Künze JK, Dalpiaz A, et al. (2006) Allosteric modulation, thermodynamics and binding to wild-type and mutant (T277A) adenosine A, receptors of LUF5831, a novel nonadenosine-like agonist. Br J Pharmacol 147: 533-541.

17. Borea PA, Dalpiaz A, Varani K, Guerra L, Gilli G (1995) Binding thermodynamics of adenosine $A_{2 A}$ receptor ligands. Biochem Pharmacol 49: 461-469.

18. Gessi S, Fogli E, Sacchetto V, Varani K, Merighi S, et al. (2008) Thermodynamics of $A_{2 B}$ adenosine receptor binding discriminates agonistic from antagonistic behaviour. Biochem Pharmacol 75: 562-569.

19. Merighi S, Varani K, Gessi S, Klotz KN, Leung E, et al. (2002) Binding thermodynamics at the human $\mathrm{A}_{3}$ adenosine receptor. Biochem Pharmacol 63 157-161.

20. Harper EA, Roberts SP, Kalindjian SB (2007) Thermodynamic analysis of ligands at cholecystokinin $\mathrm{CCK}_{2}$ receptors in rat cerebral cortex. $\mathrm{Br} \mathrm{J}$ Pharmacol 151: $1352-1367$

21. Merighi S, Simioni C, Gessi S, Varani K, Borea PA (2010) Binding thermodynamics at the human cannabinoid $\mathrm{CB}_{1}$ and $\mathrm{CB}_{2}$ receptors. Biochem Pharmacol 79: 471-477.

22. Borea PA, Varani K, Gessi S, Gilli P, Dalpiaz A (1998) Receptor binding thermodynamics as a tool for linking drug efficacy and affinity. Farmaco 53 249-254.

23. Borea PA, Dalpiaz A, Varani K, Gilli P, Gilli G (2000) Can thermodynamic measurements of receptor binding yield information on drug affinity and efficacy? Biochem Pharmacol 60:1549-1556.

24. Gilli P, Gilli G, Borea PA, Varani K, Scatturin A, et al. (2005) Binding thermodynamics as a tool to investigate the mechanisms of drug-receptor interactions: Thermodynamics of cytoplasmic steroid/nuclear receptors in comparison with membrane receptors. J Med Chem 48: 2026-2035.

25. Wagner E, Wittmann HJ, Elz S, Strasser A (2011) Mepyramin-JNJ7777120 hybrid compounds show high affinity to $\mathrm{hH}_{1} \mathrm{R}$, but low affinity to $\mathrm{hH}_{4} \mathrm{R}$. Bioorg Med Chem Lett 29: 6274-6280.

26. Strasser A, Wittmann HJ (2013) Modelling of GPCRs, Springer, DO 10.1007/978-94-007-4596-4.

27. Ferenczy GG, Keserü GM (2010) Thermodynamic guided lead discovery and optimization. Drug Discov Today 15: 919-932.

28. Strasser A, Wittmann HJ, Kunze M, Elz S, Seifert R (2009) Molecular basis for the selective interaction of synthetic agonists with the human histamine $\mathrm{H}_{\text {- }}$ receptor compared with the guinea pig $\mathrm{H}_{1}$-receptor. Mol Pharmacol 75: 454 465

29. Straatsma TP, McCammon JA (1991) Multiconfiguration thermodynamic integration. J Chem Phys 95: 1175-1188.

30. Villa A, Mark AE (2002) Calculation of the free energy of solvation for natura analogs of amino acid side chains. J Comput Chem 23: 548-553.

31. Wittmann HJ, Elz S, Seifert R, Strasser A (2011) $\mathrm{N}$-methylated phenylhistamine exhibit affinity to the $\mathrm{hH}_{4} \mathrm{R}$-a pharmacological and molecular modelling study Naunyn-Schmiedebergs Arch Pharmacol 384: 287-299.

32. Eyring $\mathrm{H}$ (1935) The activated complex in chemical reactions. J Chem Phys 3: 107-115.

33. Laidler KJ, King MC (1983) The development of transition state theory. J Phys Chem 87: 2657-2664.

34. Wittmann HJ, Seifert R, Strasser A (2011) Influence of the N-terminus and the E2-loop onto the binding kinetics of the antagonist mepyramin and the partia agonist phenoprodifen to H R. Biochem Pharmacol 82: 1910-1918.

35. Strasser A, Striegl B, Wittmann HJ, Seifert R (2008) Pharmacological profile of histaprodifens at four recombinant $\mathrm{H}_{1}$ receptor species isoforms. J Pharmacol Exp Ther 324: 60-71. 